\title{
Corpo e música pontos de encontro da negritude brasileira
}

\author{
LIMA, Ari. O que fazer com o cabelo de Marly? Estudos sobre \\ relações raciais e música negra. Salvador: EDUNEB, 2017.
}

\author{
Adilton da Cruz Santana ${ }^{1}$ \\ https://orcid.org/0000-0002-0677-853X
}

Em O que fazer com o cabelo de Marly? estudos sobre relações raciais e música negra, do Professor Ari Lima doutor em Antropologia Social pela Universidade de Brasília (2003), mestre em Comunicação e Cultura pela Universidade Federal do Rio de Janeiro (1995), graduado em Comunicação Social pela Universidade Federal da Bahia (1990). O autor é também professor permanente do Programa de Pós-Graduação em Crítica Cultura e líder do Grupo de Pesquisa Núcleo das Tradições Orais e Patrimônio Imaterial (Nutopia) da Universidade do Estado da Bahia. A obra que reúne diferentes artigos sobre música, subjetividades negras, relações de gênero com enfoque nas questões raciais, afirmação identitária por meio da estética dos cabelos negros e além tudo isso reflete a percepção das subjetividades negras em um país que subjuga e condena o corpo negro. Mas quem é Marly, questão que intitula o título da obra? Qual é sua relação com estética, negritude e afirmação identitária? Marly é irmã do autor.

\begin{abstract}
Sobre o título desta obra, preciso explicar que "Marly" é o nome de minha irmã caçula. Fomos os dois últimos filhos - sete mulheres e cinco homens - em uma família formada por pai, mãe e agregados. [...] Lembro que ao iniciar sua entrada na adolescência e preparação para o mundo adulto feminino, discretamente, acompanhei empolgados debates entre as mulheres adultas da casa sobre "o que fazer com o cabelo de Marly?" [...] A oportunidade de acompanhar aqueles debates, mais tarde, me levou a entender uma importante sutura no processo de construção, aceitação e rejeição do copo e do cabelo negros (LIMA, 2017, p. 23).
\end{abstract}

\footnotetext{
${ }^{1}$ Graduado em Letras com habilitação em Língua Inglesa (UNEB). Mestrando do Programa de Pós-Graduação em Crítica Cultural, Universidade do Estado da Bahia (Pós-Crítica/UNEB). E-mail: adilton.zurc@gmail.com
} 
Numa tessitura que beira os contrastes biográficos e acadêmicos Ari conduz essa grande questão ao longo de sete artigos publicados durante a sua carreira acadêmica e que serão fios condutores na resolução desta questão.

O livro aponta-nos reflexões que saem dos fios crespos dos cabelos negros e perpassam essa corporeidade demarcada pelo crivo da tez, não é um mero questionamento, é um pensar a estética negra que traz consigo todas as tensões e problemáticas de um povo negro. A análise de tais questões será conduzida pela visão do antropólogo que desmembra parte de sua pesquisa durante o doutorado e ao longo do livro acura o olhar sobre as identidades negras articuladas ao pensamento da música baiana, especificamente as produções dessas subjetividades, o samba baiano. A produção musical dos negros baianos é área de interesse do pesquisador cuja análise deste grupo evidencia as relações sociais empreendidas por eles nas experiências musicais marcadas por elementos que se vinculam a estética desses grupos, atrelada a isso a relação com apresentação e manipulação dos cabelos crespos.

O cabelo negro tem sido um importante instrumento de empoderamento das populações negras espalhadas mundo a fora, pois além de afirmar uma identidade que se quer política, descentraliza os discursos de representação hegemônicos da branquitude. Desde o emergente movimento dos afro-americanos na década de 60 pelos direitos civis das populações negras nos Estados Unidos a estética dos cabelos "black power" reproduziram um ideário de reconhecimento das raízes africanas como força motriz na superação dos domínios sobre os corpos escravizados, além do símbolo de luta dos negros. Nos interstícios dessas identidades está a percepção da musicalidade do samba que intercambia as vicissitudes culturais dos negros baianos e cariocas.

Nos textos Do samba carioca urbano e industrial ao samba nacional mestiço e Tradição, história e espirais no samba de roda baiano há aproximações temáticas, porém diferem-se na abordagem. O primeiro texto faz referência ao samba baiano, entretanto, constata a ausência de publicações sobre o samba na Bahia enquanto o samba carioca urbano é o gênero musical mais consumido com vasta produção o autor faz um levantamento desses trabalhos. O segundo artigo que integra o livro parte do pressuposto de que as culturas tradicionais são invenções sociais que se opõem à noção de tradição cristalizada, no tempo e espaço.

Diante do exposto o pesquisador passeia pela história originária dos africanos, para situar a ideia de tradição como recurso transmissor da palavra, nas comunidades orais africanas, em seguida situa o samba como patrimônio imaterial, sem deixar de lado as subjetividades negras que produzem e materializam esse patrimônio. Para Lima (2017, p. 96) [...] é chegada a hora de se colocar uma tradição popular e subalterna, o samba de roda, sobretudo, como uma 
questão de ordem de uma política pública e cultural, deslocando-o da condição de objeto puramente científico, estético ou de mercado. Nesse pensamento do autor está o potencial da pesquisa relacionada ao samba, ou seja, retirá-lo de um estado cristalizado para uma mobilidade cultural que thes confira não apenas o destaque merecido como o reconhecimento de sua importância ligado intimamente as identidades que o produz.

Em O fenômeno Timbalada: cultura nacional afro-pop e juventude baiana negromestiça, Lima trata das sociabilidades juvenis baianas através da música. A música é para os jovens negros e mestiços baianos uma forma de reflexão da consciência étnica é por meio delas que eles reelaboram suas identidades como forma de pertencimento e estabelecimento social. Este trabalho coaduna com as representações dos artistas dos grupos musicais locais em Black ou brau: música e subjetividade negra num contexto global, quarto artigo que traz os artistas afrobaianos da música baiana que se consagraram no cenário musical midiático e que, portanto, serão difusoras das identidades negras e modelos sociais a serem copiados pela juventude negra. Carlinhos Brown, criador da banda Timbalada, figura notoriamente conhecida pelas suas composições e filiações artísticas nacionais, os grupos culturais llê Aiyê e Olodum são referenciais importantes para juventude, pois tais figuras do cenário musical ampliam e reafirmam aspectos das identidades negras tornando-as assim símbolos sedutores o que thes confere destaque e atenção na disputa do mercadológico da música.

No quinto artigo, Da ilha dos sapos à ilha da fantasia: reterritorialização e identidade negra, o título surge como uma espécie de chamariz bastante característico para situar a questão da identidade negra nos processos que agenciam a pertença dessas identidades negras aos seus respectivos territórios bem como a prática de reterritorialização. As identidades são também narrativas territoriais transitórias elas definem o lugar de representação dos indivíduos e os discursos por eles assumidos dentro de seus territórios. As subjetividades apresentadas pelo pesquisador os territórios assumirão posições fundamentais na configuração de suas identidades.

Nessa sexta seção do livro em Funkeiros, timbaleiros e pagodeiros: notas sobre juventude e música negra na cidade de Salvador, a temática juventude negra e música continuam. Temos aqui as experiências vivenciadas através da música pelos jovens negros tais como marcas identitárias, crítica social, e construção de hierarquias raciais, de classe e gênero. Por fim o livro encerra com o sétimo artigo intitulado, Testemunhos e narrativas Brown: sobre música negra e o negro no Brasil, o artigo articula questões relativas "ao negro no Brasil" as obras de duas personalidades negras no cenário musical brasileiras os Browns: o baiano Carlinhos Brown e o paulista Mano Brown. Para Lima ambos trazem em suas produções questões que tematizam identidades fragmentadas, produção artística simbólica e cultural, o corpo negro, tradição e 
diálogo com a cultura de massa e a tradição afro-brasileira. Segundo o autor ambos possuem histórias de vidas semelhantes são expoentes do cenário musical nacional, situam-se na mesma linha enquanto músicos negros na realidade conjuntural brasileira, porém caminham a mãos separadas quando formulam seus discursos relacionados à questão racial. Enquanto Mano Brown desenvolve um discurso que reforça a diferença racial Carlinhos Brown tende para um discurso universalista.

Este trabalho lança um olhar sobre a antropologia das identidades negras pelas vias etnográficas que não divisam e nem se deixa perder de vista a problemática que faz emergir das brumas racistas as corporeidades negras subjugadas. Estudá-las é alargar questão central feita pelo autor, O que fazer com o cabelo de Marly?, mas também o que que fazer com o corpo, a consciência, a história, e a condição social negra em um país que convoca ao mesmo tempo em que interdita a cidadania e condição de sujeito negro? (LIMA, 2017, p. 27) Deixemos a questão reverberar a sociedade numa tentativa de possíveis respostas. 